\title{
Geotechnical Problems of Tartu Old Town
}

\author{
Mait Mets ${ }^{1}$, Vello Pallav², Rauno Raudsepp ${ }^{3}$ \\ ${ }^{1,2}$ Institute of Forestry and Rural Engineering, Department of rural engineering, \\ Estonian University of Life Sciences, Tartu, Estonia \\ ${ }^{3}$ Bureau of Geodesy and Engineering Geology Ltd, Tallinn, Estonia \\ E-mails: ${ }^{2} m a i t . m e t s @ g m a i l . c o m ;{ }^{2} v e l l o . p a l l a v @ e m u . e e\left(c o r r e s p o n d i n g\right.$ author); ${ }^{3}$ rauno.raudsepp@reib.ee
}

\begin{abstract}
This article analyses the formation of soil properties and the behaviour of buildings in Tartu Old Town. For assessing this, data was gathered from settled constructions, which showed that geotechnical actions change the properties of fluvial sediments variously and as such need thorough research. The preservation of wood used in foundations depends on their placement in geological layers, on the fluctuations of surface water and the geotechnical solutions used. The effects of geotechnical actions conducted before need more attention and therefore new projectsolutions in Tartu Old Town need thorough geotechnical research in each case.
\end{abstract}

Keywords: fluvial sediments, properties of fluvial sediments, fluidness of fluvial sediment properties, building behaviour, timber behaviour in soil.

Conference topic: Geotechnical art and historical experiences.

\section{Introduction}

During it's long history Tartu has been destroyed and rebuilt (Pallav, Mets 2013). Because of this, the fill - a thick cultural layer of, - up to 3.5 meters, has accumulated. The weight of buildings, the heat from fires and the weight of fill have all affected weaker soils under the fill - fluvial sediments, compressed them and changed their geotechnical structure (firmness and compressibility).

As the influence has been long (close to a thousand years) and many effects and processes have reached an equilibrium, their activity today is small and partially they have faded. Human action has caused new effects and processes which influence the behaviour of buildings.

\section{Geological characterisation of Old Tartu}

Tartu sub-city's geological cross-section can be seen on Figure 1.

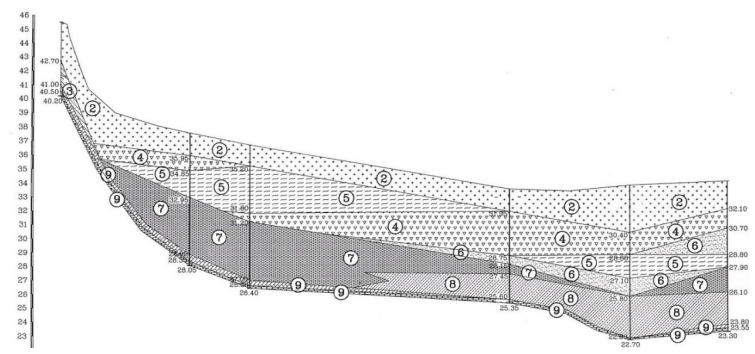

Fig. 1. Conceptual geological section of Old Tartu $1-$ topsoil, fill; 2 - fill; 3 - fine sand, silt(collovium); 4 - peat; 5 - spring and lake lime; 6 - fine sand with organic matter; 7 - fine to medium sand; 8 - varved clay; 9 - Devonian sediments
Downtown Tartu sub-city is founded on the fluvial terraces of river Emajõgi and is confined by the terrace of the river on one side and by the river itself on the other.

The base layer Devonian Aruküla stage sediments in this area 2.5 to 15 meters deep and represented by Devon clay and sandstone.

Sandstones are soft rocks and their compressive strength stays between 1 and $10 \mathrm{MPa}$. When crumbling the cementation between particles dissappears and they break down to medium sands $I_{d}=0.4 \ldots 0.55$.

Clays are medium plastic soils, their firmness depends upon the quantity of micro-fissures characterized by water content $W_{n}$ (Table 1 ).

Table 1. Undrained shear strength $C_{u}$ depending upon water content $W_{n}$

\begin{tabular}{c|c|c|c|c}
\hline $\begin{array}{c}\text { Water content } \\
W_{n} \%\end{array}$ & $10 \ldots 15$ & $16 \ldots 20$ & $21 \ldots 25$ & $26 \ldots 30$ \\
\hline $\begin{array}{c}\text { Undrained shear } \\
\text { strength } C_{u} \mathrm{kPA}\end{array}$ & $200-140$ & $130-90$ & $85-45$ & $40-30$ \\
\hline
\end{tabular}

Micro-fissures appear due to weathering and the crumbled part reaches $2 \ldots 8$ meters deep from the clay layer. Under water clays may swell, the quantity of micro-fissures may increase and their firmness decrease.

During the archaeological research accompanying the building of Tartu Private Bank the water content of clays rose from $17 \ldots 10 \%$ to $26 \ldots 29 \%$ and their strength $C_{u}$ decreased from 125 down to $35 \mathrm{kPa}$. Plate-stresstests performed upon clays showed significant correlation between fixed creep point $q_{y}$ and undrained shear strength $C_{u}: \varphi$

$$
q_{y}=4 C_{u},
$$

$q_{y}$ - creep - level; $C_{u}$ - undrained shear strength. 
Devon sediments are partly covered with a thin $(0.5 \ldots 1.0 \mathrm{~m})$ layer of silt, but in most part they are covered with relatively dense varved clay with a water content of $W_{n}=27 \ldots 32 \%$, and a preconsolidation ratio of 1.4...2.0.

Varved clays are covered by dense medium to fine sands and alluvial organic matter containing bouffant silty sands. These in turn are covered by fluvial sediments, lake lime, peat and mud.

In time varved clay has not changed much and it's properties under and around buildings are similar. This is explained by the effect from the weight of buildings, historical pre-consolidation and good draining conditions.

Significant changes have taken place with fluvial sediments in time and it is recommended to take these properties into account when building in order to make the right decisions during planning.

Spring lime is a calcareous macroporous soil, with a water content of $50 \ldots 100 \%$, which has a an unit weight depending on the content of organic material and iron-cement of $20 \ldots 30 \mathrm{kN} / \mathrm{m}^{2}$.

The water content of spring lime practically does not depend on the depth the sample is taken from and spring-lime samples examined so far have retained their structure and have not turned into calcareous sand under the weight of buildings or been affected by other factors (Käär 1973).

The drained shear strength of spring lime is $\varphi=$ $20 \ldots 26^{\circ}$ and $C=5 \ldots 8 \mathrm{kPa}$.

Undrained shear strength $C_{u}=60 \ldots 80 \mathrm{kPa}$. In compression conditions dinsintegration of macroporous structure has not been noted even on pressures up to $0.5 \mathrm{MPa}$. The studies of spring-lime have not shown any difference in samples taken from under buildings and from under vacant ground. Deformation modules formed based on compression tests in different studies remain between 0.8 and $2.7 \mathrm{MPa}$.

Practically determined measurements do not depend on porosity or water content of the sample. This shows that the measured arrangements are related to surface preparation and surface deformation of the sample. This is shown also by observations of settling of new buildings, according to which the measured settlement is less than settlement calculated upon the data of compression tests (Oll 1967a; Jaaniso, Oll 1976; Oll, Jaaniso 1991). Single plate tests conducted on spring lime (cases of contact infringement) estimate springlimes compressibility to be $3 \ldots 4$ times smaller. If we estimate the deformation module of spring-lime to be $15 \mathrm{MPa}$, the calculated and measured settlement.

Fluvial sediments contain the most lake lime in Tartu Old Town. This highly calcareous organic material containing substance seems to be be a varied since it's water content and porocity are different: $W_{n}=$ $55 \ldots 195 \%$ and $I_{p}=1.5 \ldots 5 \%$. Lake-lime calcium carbonate content is $75 \ldots 95 \%$ and organic material content $5 . .20 \%$. Organic matter content affects the unit weight of lake-lime, which is $1.75 \ldots 2.6 \mathrm{~g} / \mathrm{cm}^{3}$.
Drained shear strength measurements generally overstate the strength of lake-lime - the angle of internal friction is $18-26^{\circ}$ and cohesiveness $15 \ldots 30 \mathrm{kPa}$. Undrained shear strength is directly tied to lake-lime's geotechincal history. The undrained shear strength of soil located under buildings (water content has diminished $55 . .80 \%$ ) is

$$
C_{u}=70 \ldots 80 \mathrm{kPa} .
$$

Macerals with a water content of $100 \ldots 130 \%$ have $C_{u}=50 \ldots 60 \mathrm{kPa}$ and undensified macerals with $W_{n}=$ $140 \ldots 170 \%$ have $C_{u}=20 \ldots 35 \mathrm{kPa}$.

Lake-lime's compressibility depends on the density developed during geotechincal history. Deformation modules of undensified macerals with a natural structure are $0.4 \ldots 07 \mathrm{MPa}$ and of densified macerals are 1.3...2.2 MPa.

\section{Peat}

During the city's geotechincal history peat's geotechincal nature has changed greatly (Table 2). Peat's water content in Tartu remains $120 . .550 \%$ and is directly linked to the position of the peat layer in the geological cross-section and to the compressing pressure (weight of the filling soil and the building).

Table 2. Peat's geotechincal properties

\begin{tabular}{c|c|c|c|c}
\hline \multirow{2}{*}{$\begin{array}{c}\text { Water } \\
\text { content } \\
\begin{array}{c}W_{n} \\
\%\end{array}\end{array}$} & $\begin{array}{c}\text { Drained shear strength } \\
\text { Angle of } \\
\text { internal } \\
\text { friction } \\
\varphi^{0}\end{array}$ & $\begin{array}{c}C \\
\mathrm{kPa}\end{array}$ & $\begin{array}{c}\text { Undrained } \\
\text { shear } \\
\text { strength } \\
C_{u} \\
\mathrm{kPa}\end{array}$ & $\begin{array}{c}\text { Total } \\
\text { Elasticity } \\
\text { Module } \\
E\end{array}$ \\
\hline 100 & 28 & 15 & 23 & 0,7 \\
\hline 200 & 20 & 9 & 20 & 0,5 \\
\hline 300 & 18 & 7 & 17 & 0,3 \\
\hline 400 & 17 & 5 & 15 & 0,2 \\
\hline
\end{tabular}

Muds, being the topmost fluvial sediments, have changed the most during geotechnical history. They have densified under fill and buildings and have often mixed with construction debris and fill.

With the orginial water content of $160 \ldots .200 \%$ mud was at places a "heavy liquid" with a shear strength of $2 \ldots 5 \mathrm{kPa}$. Mud is characterized by a high organic matter content $-8 \ldots 17 \%$, high plasticity and liquid limits and a small plasticity index of 2 ...6.

Alongside densifying mud's water content has decreased $50 \ldots 100 \%$ and it's shear strength has gone up, $C_{u}=10 \ldots 40 \mathrm{kPa}$. In single cases by mixing with construction debris the undrained shear strength of mud has gone up to $80 \mathrm{kPa}$.

The described fluvial sediments are covered by fill. The content of this soil varies, but tests conducted on different soil have given suprisingly coherent results: creep limit $0.1 \mathrm{MPa}$ and deformation module $5 \mathrm{MPa}$ at creep limit. 


\section{Behaviour of buildings on fluvial terraces}

Behaviour of buildings on fluvial terraces largely falls into two categories.

Firstly buildings constructed after World War II. Most of these, built after 1951, are built on piles, their settlements stays in the range of $1 . . .2 \mathrm{~cm}$ and remarkable deformations are not present. Still some buildings were constructed on shallow foundatins and their settlements were being monitored. The behaviour of these buildings has been analysed by M. Jaaniso, N. Oll and R. Käär (Oll 1967a, 1967b, 1976; Käär 1973).

Predictions about the settlements of these buildings were based on thorough geotechnical research and the deformation properties of all soils were determined with compression tests. Predictions regarding the settlements have been given based on these results. Settlements observations have shown that predictions exeeded actual settlements and M. Jaaniso and N. Oll proposed that this was caused by the overestimation of the compressibility of spring lime (Jaaniso, Oll 1976).

$50 \%$ of the settlements takes place during the construction process. Settlement speed also slows down to $1 . . .2 \mathrm{~mm} / 100$ days for $10-20$ years and then practically subsides. The monitoring of settlements has shown that it is possible to construct 3-5 storied buildings on shallow foundations and the accompanying settlements of $20 \mathrm{~cm}$ is not an issue.

With older buildings the situation is more complicated. Some of these buildings have settled unevenly, while unexpected intensive settling have lately significantly decreased.

The clothing store at Rüütli st. 11 sank unevenly and became unstable. In this case it was recommended to take cellar rooms into use. During the cleaning of the cellar soil counter-weight affecting the foundations was decreased, some parts of the foundation moved causing the foundations to reach its. After restoring the counterweight, the deformations subsided. Later the building was strengthened with injection piles and then the building has settled 0...1 mm in 8 years (Mets, Parbo 1999).

A second gravely settled building is the main building of the University of Tartu, Figure 2.

The building is constructed on timber piles (1804...1805) and behaved well until 1965. Then fissures appeared and settlements monitoring showed remarkable settlement. Under the lead of N. Oll extensive inspection were conducted to find out the reasons for the deformations. It was found that the grillage and piles heads had been partly damaged by the larvae of the wood weevil (Cossonus parallelepipedus). The scale of damage varied and so did the settlements. The settling caused by these larvaethat had started in 1966.a. intensified in 1968.a. and went on until 1980. The scale of the settlement was $20 \ldots 180 \mathrm{~mm}$. (Oll 1976). After strengthening the foundations by adding steel piles and later injection piles the settlements practically ended. (Avellan et al. 2005).

As can be seen from Figure 3. These cases of building settlements are not hazardous and may just invite the need to conduct routine repairs more often. Of these buildings only the foundations of the Tartu City Hall (Figs 4, 5) have been reinforced with injection piles. This building is situated on a hillside, where the thickness of softer soils varies and the construction has been built on timber piles. A considerable decline in the level of surfacewater had caused the formation of fissures and because of this, it was decided to reinforce the foundations with injection piles. Since then the building practically has not settle.

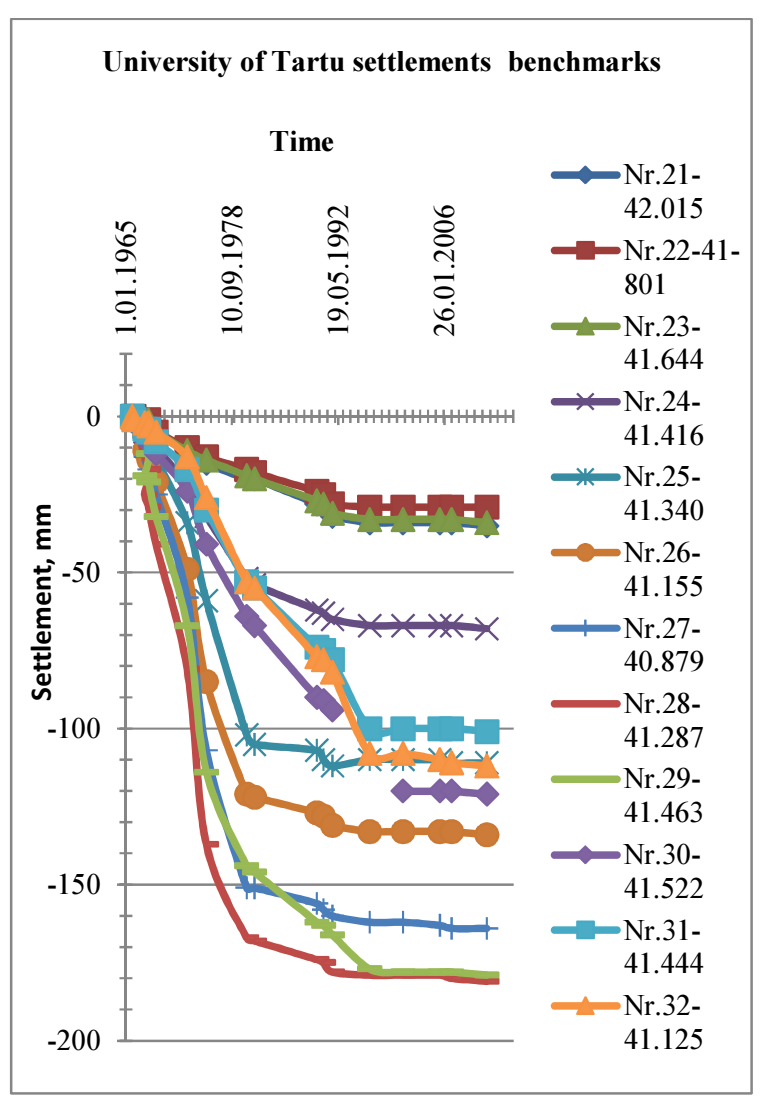

Fig. 2. Universitys of Tartu settlements benchmarks

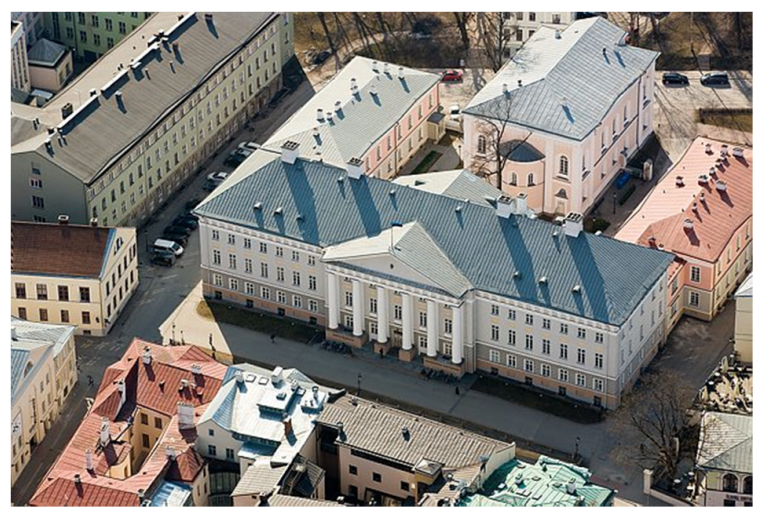

Fig. 3. The main building of the University of Tartu (O. Maidla) 


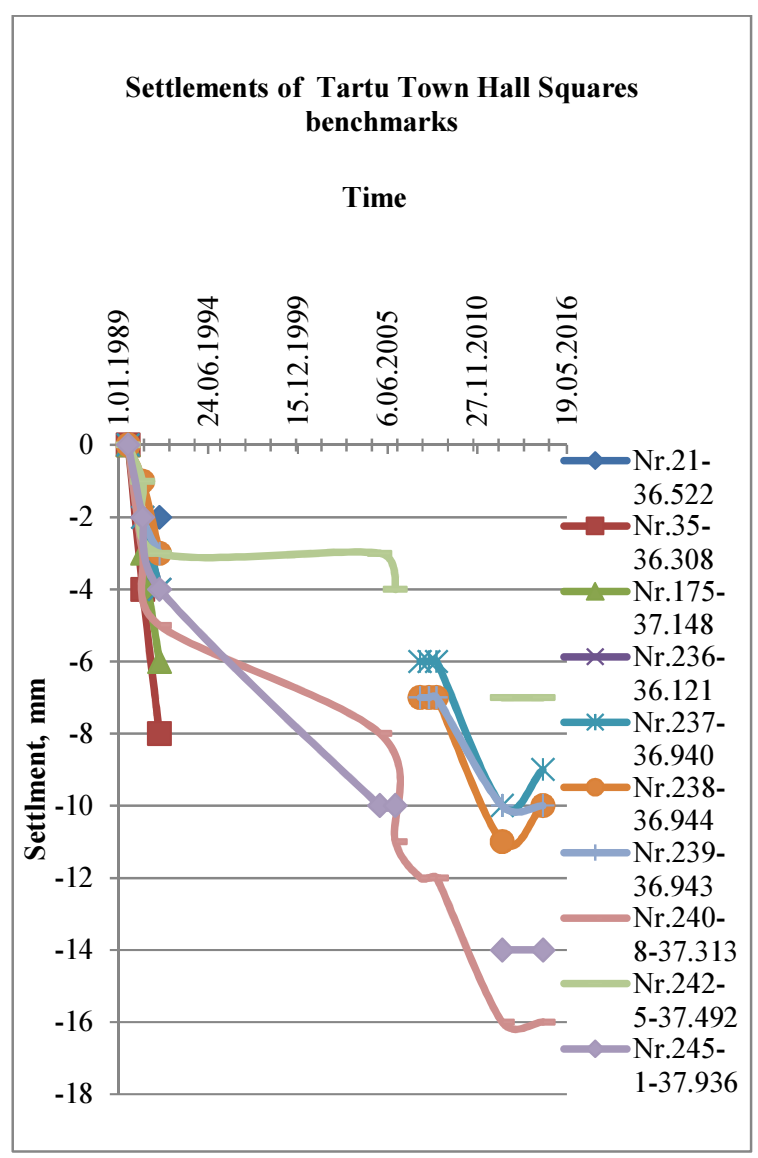

Fig. 4. Settlements of Tartu Town Hall Squares benchmarks

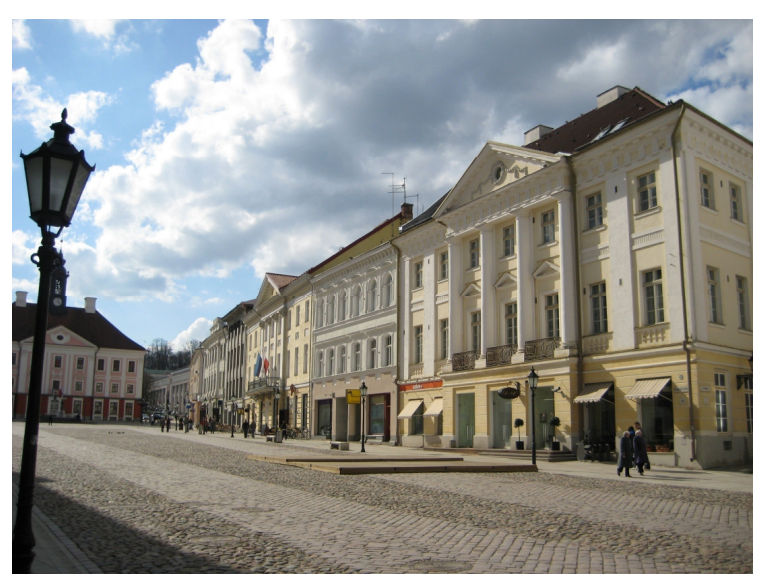

Fig. 5. Tartu Town Hall Squares (V. Pallav)

The building located at Ülikooli St. 16 was built during 1780-1785 on a low foundation, resting on lake lime (Mets et al. 2013). Natural undensed lake lime's water content was $120 \ldots 130 \%$. Under the building the lake limes water content is $60 \ldots 70 \%$, and the samples taken 25 years ago show the same water content. The surface of the lake lime layerunder the building is at an angle of $1.4^{0}$. Next to this building another building was being rebuilt and a trench was dug to implement drainage, hydroisolation and insulation. This trench remained open for almost a year. Later it was filled by vibrating the soil and the building sufared horizontal displacement by moving $3 . . .4 \mathrm{~cm}$ horizontally. Vertical settlements remained under $2 \mathrm{~cm}$. The building was reinforced with injection piles to stop further horizontal placements and since then the building has stopped settling.

\section{Conclusions}

1. Fluvial sediment properties have changed under the weight of buildings and fill and to be examined in every specific case.

2. The preservation of wood in the lime sediments of Tartu is good, but fluctuation in the level of surface water causes additional settlement of buldings.

3. Reinforcing of old buildins must be preceded by thorough geotoechnical inspections and based on this, the right decisions can be made as to further geotechnical action.

\section{References}

Avellan, K.; Maanas, M.; Jaaniso, V. 2005. Strenghtening the foundation of main building of Tartu University, in Proceedings of the $16^{\text {th }}$ International Conference on Soil Mechanics and Geotechnical Engineering: $16^{\text {th }}$ International Conference on Soil Mechanics and Geotechnical Engineering, 12-16 September 2005, Osaka, Japan, 2747-2751.

Jaaniso, M.; Oll, N. 1976. Allikalubja pikaajaliste kompressioonteimide tulemustest, VI Eesti Geotehnika konverentsi teesid. Tallinn, 52-53.

Käär, R. 1973. Eesti eripinnaste geotehnilisest eripärast: Diplomitöö. Tartu.

Mets, M.; Parbo, A. 1999. AS Michael Abakhani kaubamaja Tartus, Rüütli tn.11/Gildi 7, vundamentide uuring. $A S$ GEOTEHNIKA IB Geotehnika aruanne 898-1. Tallinn.

Mets, M.; Mussatova, J.; Raudsepp, R.; Pallav, V. 2013. Performance of historical buildings and geotechnical characteristics in Estonia, in Y. Iwasaki (Ed.). Workshop on GeoEngineering for Conservation of Cultural Heritage: ATC19 Workshop in $18^{\text {th }}$ ICSMGE, Paris, September 2013, Role of Geo Engineering for Conservation of World Heritage. Osaka, Japan: GeoResearch Institute, Department of World Heritage, Cyber University, 103-108.

Oll, N. 1967a. Ehitiste vajumiste ja deformatsioonide uurimisest Tartus. Ehitusgeoloogia kogemus II. Tallinn, 107-115.

Oll, N. 1976. Puidu säilivus Tartu Riikliku Ülikooli peahoone vundamendis. Ehitusgeoloogia kogumik-III. Tallinn, 115-126.

Oll, N.; Jaaniso, M. 1991. Ehitusgeoloogiline uurimine Tartus aastatel 1935-1960. Tallinn, 176-190.

Oll, N. 1967b. Puidu säilivus parvaluses ja vaiades, Ehitusgeoloogia kogumik- II. Tallinn, 89-96.

Pallav, V.; Mets, M. 2013. The history of the foundations in Tartu, in Baltic Piling. London, UK: Taylor \& Francis Group, 37-45. http://dx.doi.org/10.1201/b15697-5 